\title{
Combine Effect of Automated Services and Traditional Services Quality on Customer Satisfaction: Evidence from Banking Sector of Pakistan \\ Malik Shahzad Shabbir ${ }^{1 *}$, Amer Khalil ur Rehma ${ }^{1}$ and Tazeem Shabbir ${ }^{2}$
}

${ }^{1}$ International Islamic University, Islamabad, Pakistan

${ }^{2}$ University of Punjab, Pakistan

\begin{abstract}
In recent years, the use of technology to deliver the services has grown rapidly in banking sector and it made a significant impact on customer perception. In previous studies; automated service quality was proposed by the several studies to be an important antecedent of customer satisfaction. However, in traditional settings, human element is also considered a strong motivator of customer's satisfaction. So the major objective of this research study was to explore the combined effects of automated service and traditional service quality (human interaction) on customer satisfaction. Furthermore, the investigation on customer satisfaction in automated services context, combine with traditional services quality is limited. However, we didn't find any comprehensive study that has modeled these variables together. The research study was conducted through cross sectional field survey and self-administrated questionnaire was used in order to collect data in banking sector of Pakistan. Multiple regression analysis process was conducted to assess the effect of both services typology (automated and traditional) on customer satisfaction. The results have shown three main findings. First, it was found that automated service and traditional service quality (human interaction) both have direct significant effect on customer satisfaction. Second, the results find that an insignificant relationship between ATM services on customer satisfaction when moderated by Traditional Banking services, and directly this services play an important role to satisfy the customer. Thirdly, results found a strong positive significant association in Mobile banking services and internet banking services moderated by teller banking services.
\end{abstract}

Keywords: Automated and traditional service quality; Customer satisfaction; Banking sector; Mobile and internet banking services

\section{Introduction}

Service quality has seen as the major way to increase organizational performance and an important way of organizing a flourishing business in recent economies [1]. It remains considerable the important issue in the literature of marketing. So customer satisfaction and service quality is the core heart of the industry of banking. In the consideration of a successful banking business rely on the strongly related impact of perception and the expectation of the customers [2,3]. Testing the market oriented customer expectations, scheming a system for service delivery that can satisfy the needs of customers and improve the level of performance is an imperative objective for banks to attain and retain the quality of being competitive [4].

However during last two decades technology has significantly caused reshaping of banking industry. The revolution in technology and communication created a new world for banks; a world in where consumers are enable to directly interact and conduct their transaction services anytime and anywhere [5]. Technology has changed the way of retail banking by creating new range of products and improving use of automated delivery channels. The automated delivery Channel include as internet, mobile banking and ATM [6]. Anyhow In the literature, automated banking channels have several different names such as technology delivery systems, electron banking, online banking and innovative distribution channels.

Automated service qualities have been taken as an important feature to measure the satisfaction of the customers [7]. As Al-hawari [8], argued that banking advance automated service quality can enhance the satisfaction, retention and profitability and strengthening relationships with customers [9]. All over the banking industry has to face a critical condition where the traditional delivery services are not the first priority of the interest [10]. Meanwhile, many researchers argued that customers can be isolated from the technology, suggest ineffectiveness, and it can increase the chances of separation and passivity [11]. However, most of the bank customers still giving importance to direct communication from the service provider. The researches argued that issue of quality in the traditional style is still a successful way of making a good relationship [12]. Therefore, banks should find a best way to enhance the competitive benefits. A few number of researchers got the similar problem. Curry and Penman [13] found that increasing use of technology in banking sector, so it is compulsory to maintain a balance between traditional banking services and the technological services. However, it is critical for bank managers to maintain the balance between traditional service qualities and automated services. So the same study investigates empirical evidence which shows the tellers have relative significance with automated banking services that can influence the satisfaction of retail banking customers. Due to the intensive growth in technology automated channel of delivering a variety of banking services has become a common trend among the banks and also considered the important issue in marketing literature. However, the literature provided limited empirical investigation that despite the intensive growth and use of technology, the traditional services are at a standstill way of making the relationship with customers.

The financial sector include banks which are play an important component of the Pakistani economy. Improving bank profitability by understanding its relationship with banking automated services quality is expected an impact on the whole national economy. This research is based on the importance of both automated banking and traditional

*Corresponding author: Malik Shahzad Shabbir, Internationa Islamic University, Islamabad, Pakistan; Tel: 0343-6656850, E-mail: Mshahzad786.pk11@gmail.com

Received December 28, 2015; Accepted January 29, 2016; Published February 02, 2016

Citation: Shabbir MS, Rehma AK, Shabbir T (2016) Combine Effect of Automated Services and Traditional Services Quality on Customer Satisfaction: Evidence from Banking Sector of Pakistan. Int J Econ Manag Sci 5: 332. doi:10.4172/21626359.1000332

Copyright: (c) 2016 Shabbir MS, et al. This is an open-access article distributed under the terms of the Creative Commons Attribution License, which permits unrestricted use, distribution, and reproduction in any medium, provided the original author and source are credited. 
banking would help in identification and understanding the customer's opinion regarding both type of banking services along with its features and how it can satisfy the customers in Pakistani banking sector. However, there were few studies in the literature that discussed the issues related to the automated banking context [14]. So this research study is very important because it will extend to the existing body of knowledge, literature and could be a landmark for further studies to be conducted on this particular field.

However, the term management is not only consisting on firm level but also for Institutions, Economy and State levels respectively [15]. It might be beneficial to the scholarly community and decision maker's body who deal directly with the banking sector and to make meaningful proposals and suggestion to improve the banking sector in Pakistan [16]. This study is also helpful in getting one step nearer to the interoperability of the technological solutions.

The results of this study can be very help full to manager's community of banks, where they take advantage of these benefits technology and traditional offers. It also provides excellent service to customers. This study will empower policy makers of financial institutions and banking sectors to know what strategic decisions are required for enhancing customer satisfaction in the current market turbulence and thus will get customers faithfulness and will increase the profit as well.

\section{Literature Review}

\section{Customer-satisfaction}

Customer satisfaction is referring to the judgments or feeling towards products or services of the customer when they have been used [17]. Over the last three decades Customer satisfaction has been fundamental components of marketing theory and practice. Customer satisfaction in the renowned services has been broadly known as basic indicator of performance regarding to any type of business. It is also on the top main priority in strategy development and market oriented firm, which cannot ignore the importance of customer satisfaction [18]. In current intense competition climate from both domestic and international market, the key to contain a competitive advantage is depending on delivering high quality services which in turn satisfies the customers. Banks now tend to focus more on financial activities, markets, and customer satisfaction than previously.

Abdullah and Rozario [19] highlighted some different external and internal factors, which may be influenced level to customer satisfaction and suggests that it is very difficult to determine satisfaction. The process of measuring overall customer satisfaction is not static but consistent change while the customer gains an experience with service provider. As Jamal and Nazar, study proposed that customer-satisfaction is not only associated with the view of customers concerning the reliability of the services delivered but also based in the experience of the customer with the delivery process. However, customer satisfaction is emphasis more on the total evaluation based on total consumption over the time [20].

\section{Technological Innovation and the banking sector}

Technology developments have been analyzed that they are the major forces which influencing the financial sector's development [21]. Technological development has changed the way of retail banking by creating new range of products and improving delivery channels. Technology has a high value for competitive advantage and this is part of marketing literature. Pyun et al., explained that banks adapt technology quickly and invest in it to control the costs, attract the valuable customers and gathering expediency and technological needs of their presented customers. According to Alu [22], technological innovations facilitate banking process not only for customers but also for the banking officers. Similarly, Yasuharu had a similar observation that technology has transformed banking industry. It concluded that technological infrastructure helps customers, all members of the value chain and helps in getting larger market share and high growth.

Technology and its predicted innovations have now become almost a standard of competitive advantage. A study by Singhal and Padmanabhan explained a relevant to customer perception towards internet banking a technologically advanced service, this study provides basis which add on to customers' perception such as convenience, reliability, time factor, real time access to information, faster transfer, easy to use, user friendly, low transaction fee, branch less banking facility, and many other factors. The importance of this can be drive through the reality that it has been supposed to throw in to energetic be beneficial to firms so they can increase their capability in keeping up with, react to and start technical improvements on the continues beginnings. So it can be disguised for services industry and novelty plays an important role in communication with the customers [23].

In current intense competitive economy, high services quality plays a significant role in a company's success and failure [24]. This creates a tremendous pressure on banks to improve their services [25]. Provision of automated services are necessary in a bank because it enhance customers rotation rate, productivity, financial performance, helps attract new customers through positive word-of-mouth, decrease operation cost and maximizing competitive advantages [26]. It is necessary for banks to embrace this new technology oriented context, because in current competitive environment, information technology has become back of modern manufacturing utilization and main cause of intended for the expansion. Cronin and Taylor [27] argue that customer satisfaction directly linked with the enhancement of an organization's services. Most of the scholars have mentioned that innovation and Service quality are the primary aspect for the assessment of customer satisfaction [28]. In the delivery of service, banks need to technological innovation to meet the needs of numerous clients being both corporate and private customers.

Today, technology is the major force behind the change occurring in the business world, which is creating new marketing opportunities. Technology has also impacted on marketing practice [29]. This change is at its peak and is unavoidable for survival. So adaption is necessary for competitive advantage and point of differentiation [30]. The acceptance of IT infrastructure as a way to have dealings is extremely fetching famous. If businesses are unable to develop channel from where their customers can gain value, they will be having troubles with developing relationships with the customers [31].

\section{Automated services}

Anyhow In the literature, automated banking channels have several different names such as technology delivery systems, electron banking, online banking and innovative distribution channels [32,33]. Automated service refers to the electronic provision of a service to customers. By definition, as the customer's overall evaluation of the excellence of services provided through electronic networks or media, such as the internet, ATM, and telephone banking [34]. It is a comprehensive definition which seemed to be fit for this research because as the internet delivery channels is not the only automated service delivery channel that can be identified in the banking sector, ATM and telephone banking are also include. 
In the retail banking sector, customer's tendency to use new automated channels of service deliverance can took into place a striking Adjustments and build close association with their customers [35], and also provide other benefits, such as convenience, lower cost, increased sales [36]. Scholars have also been identified some other key benefits as including better customer retention; attraction of new customers; increased profit and performs and enhanced corporate image performance $[37,38]$ their studies have a positive impact on the growth in banking sector.

Because of the importance of automated services in banks, there is a necessity to understand better how customers evaluate automated banking services. The customer acceptance of the new automated channels of service delivery in banks may bring a dramatic change in the way that retail banks build and maintain a close relationship with their customers. So, there is a small amount of studies that investigate automated service quality features in banking sector [39]. Thus, there is a need for further empirical investigation on automated service quality in the banking sector

Litterateur showed that in the banking sector use of these three automated service delivery channels by customers in a complementary way [40]. As a result, creating relationship with customer more preferably in combination but it can be developed using any of them [41]. Customer intention to use a particular channel is perceived directly by perception of the features associated with a particular channel. The quality of each channel of automated services is important in shaping the customer's overall perception and therefore, each delivery channel has been measured as a different factor in the proposed automated service quality model rather than an aggregated measurement.

Among the retail customers Internet banking (IB) is getting growing popularity due to its 24 hours availability in seven days a week, low cost transaction, and due to have ability serve up as an alternative convenient channel. In other word, there is no time and place constrained in internet banking. As a result, internet kind of banking has attracted substantial adoption by the customers. The major and most important features of IB have been found such as, time saving, freedom from time and place and low cost.

Casalo et al. argued that the website usability of higher levels may lead to words higher levels of affective customer's commitment to the website as well a direct, constructive and considerable relationship between customer's satisfaction and commitment to a financial services website. Alawatte found that the convenience use of internet banking is a key source of customer satisfaction and thus, affect the attitude of customer adoption of internet banking. The work done by Jun et al. [42] was also found that reliability of IB services to be a very significant predictor of customer satisfaction. Internets banking web responsiveness, assistance, assurance and empathy have a significant effect on customer satisfaction at similar levels. Some other researchers such as has also been illustrated that these internet service quality dimensions (assurance and responsiveness) have high significance impact on customer satisfaction in internet retail settings. The impact of internet service quality on customer satisfaction plays a very important role to create a positive word of mouth [43].

\section{How does service quality impact on satisfaction in an automated banking context}

Due to inconsistency in literature, this study has a tendency to support with the moderation of traditional services quality between overall customer satisfactions and automated service quality. Moreover, the adoption trend of new technology may alter from county to country. In this way the some firms can use these technologies in their respective marketing strategies across the cultural boundaries. It is almost impossible to find that any previous study has investigated the issue of quality in automated and traditional services complementary in their effect on customer satisfaction in the context of Pakistani conventional banking sector.

Furthermore, the research models currently proposed to determine automated service quality are not fully in their focus. However, encompassing on one technological services-channel "the internet" in that way ignoring the other attributes of automated service channels such as, mobile banking services and Automated Teller Machines (ATMs). Accordingly, the proposed model of this study which tried to cover the unique attributes of each automated delivery channel and taking into account the attributes of traditional services that have the potential to influence quality issues. This research thus bridges the gap that existed in the current body of knowledge.

\section{Service quality and customer satisfaction}

Nowadays, the main concern of business managers is to find out critical services quality performance factors that create customers satisfaction in order to survive in competition environment. Good services quality create positive attitude and provide the way that how to satisfy the customers. Kirti Dutta and Anil Dutta had an observation that expectations of customers are higher in their value in comparison to customer perceptions and this gap has high implications for customer satisfaction in the banking sector. Vanpariya and Ganguly also had an observation empirically proven that customer satisfaction and service quality is highly and significantly linked with each other. Which in turn generate positive word of mouth and loyalty intention? Satisfaction has never been influenced by other factors of demographics except income, endorsed that all factors of customer satisfaction are linked to service qualities. Gopalakrishnan et al. found that service quality predicts customer satisfaction which in turns had an impact on retention Jackie L M, Tam had a similar observation that customer with high perception, if are endorsed by positive experience get more satisfied that other customers.

Proposed that banks should have to be concerned regarding the quality of provided services because the quality of services taken as most critical part of strategic compilation. Huseyin et al. find services quality awareness has a contribution toward meeting the criteria of International competitive environment. Bank should hire creative personals in order to maintain the long term relations with valuable customers.

\section{Moderating role of traditional services quality}

Banks play a complementary role to stable and enhance economic growth in any economy, while the operations of banks directly relay on the customer satisfaction. Traditional services quality has been an important critical moderator between the relationships of automated services and customer satisfaction. It has been identified, when personto-person interaction increased the impact of relationship between automated services and customer satisfaction went stronger [44]. This showed that while the human interaction with the customers accelerates the effect of relationship between automated banking services and customer satisfaction.

So, highly increasing population throughout the world appreciates and deliberately adopts the new advanced automated banking services 
especially e-banking landscape, customer still giving importance to human interactions while dealing with bank [45]. The way to develop dominated relationship with clients through improved online services is not the only option, customer still prefer to direct human interaction in dealing with their banks [46]. Moreover, the teller services have considerable value in devolving strong relationship between customer satisfactions and modernized e-banking services continuously. As Donnell, Durkin, and McCartan-Quinn [44], proposed that satisfaction through advanced automated technologies and personal contacts as well as has positive significant relationship.

The study proposed by Patricio et al. has further explore to measure the quality of services of different banking services through various delivery channels such as automated and traditional channels, and found that prevailing services quality with a single delivery channel has an important effect on other channel like traditional services prevail, thus the quality matters relating to automated banking services should be observed as complementary to the quality issue of normal traditional services associated rather than substitute to each other. So, these findings followed by Durkin et al. shows that a customer does not prefer automated banking as a substitute of direct face to face interaction in banking services. So banks should continuously follow up the levels of accomplishment of the personal needs of customer and satisfaction associated to organizations if they want their customers will remain satisfy from online services [46]. Semijin et al. found that in e-commerce, offline completion was only as significant as online service quality.

However, traditional banking services context is an important gap which this research attempts to address. The literature review which has been done in this research study is clearly pointing out that despite the increasing popularity and acceptance of new banking technologies and the increasing move to an e-banking landscape, customers still have a high preference for human interactions when dealing with their bank. This paper sheds some light on the debate about the balance between personal interaction and technologically delivered services must be right if customers are to be retained and satisfaction over time (Figure 1).

\section{Methodology}

Every research program has a research design that has a particular direction of methodology, which bases on its framework and purpose, such as research design, sampling techniques, data collection method

Independent variables

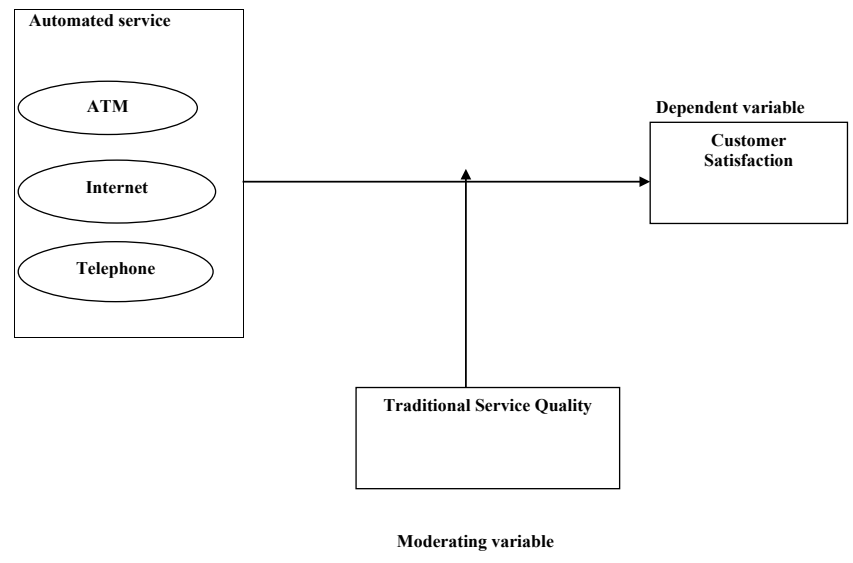

Figure 1: Theoretical framework. and data analysis methods. The framework in the collection and analysis of data is known as research design. It has been considered the road map while processing the whole process of the study, it explain the direction to conclude the research question. For the purpose of obtaining better representative samples of participants in this research study it is very much vital to determine what is the most important source of data collection from the targeted population. Sample population depicts as set of entities or people from whom results can be generalized the border population [47]. The population must be explaining clearly before that could be sampled. Main purpose of the study is to find the impact of the relationship among customer expectation from automated banking services quality, traditional service quality and customer satisfaction in Rawalpindi/Islamabad, thus in this study, the sample population consisted of bank customers in Rawalpindi/Islamabad over 18 years of age.

Questionnaire of this study has been developed as per the need of required information. Variables such as automated banking services quality, traditional service quality will be used to examine customer's satisfaction. Questionnaire for these variables will be used five point Likert type scales (Strongly Agree $=1$ and Strongly Disagree=5) to measure the respondent's response. The questionnaire consisted of closed ended questions and to avoid any ambiguity and confusion it was decided to divide the questionnaires into different sections. Section one of the questionnaire takes a look at information on the relationship between automated banking services quality (Internet, Mobile and ATM) and customer satisfaction at Rawalpindi/Islamabad Banks. Section two of the questionnaire look at whether traditional service quality banking moderate between customer satisfaction and service quality and has positive relationship service. Section three dealt with overall satisfaction and last section four dealt with general information on the participants.

The major source of primary data collection is interviews, focused group discussion and questionnaire. This study uses the primary data collection technique through questionnaire from three large banks of National Bank of Pakistan (NBP), Habib Bank of Pakistan (HBL) and Muslim Commercial Bank of Pakistan (MCB). Data collection has been done in two phases. In first step we collect the data for pilot testing of the questionnaire, because we can check through pilot testing that as items are selected from previous researches. But all these studies are being conducted in developing countries, so ti is compulsory to check the validity and reliability of the research instruments according to Pakistani situation, so respondents can easily understand the questions.

Statistical analysis tools used to analyze the data. Demographic frequencies are analyzed through correlation and multiple regression analysis with SPSS. For the purpose of testing the relationship between independent, dependent and moderating variable correlation and multiple regression analysis used. Moderating regression analysis used to test the moderating impact of traditional service quality on automated service quality and customer satisfaction. It is very much important to take a look on the accuracy of data before conducting the final analysis. The response should be consistent because inconsistent response may disturb the reliability of the data. If there is any problem with the reliability of the data the analysis may lead to incorrect conclusion.

The reliability of every item of the scale was determined by Cronbach [48]. Based on the criteria as recommended by Nunnally and Bernstein, cronbach alpha coefficient estimations of all the variables were decided on 0.70 . Cronbach alpha coefficient value for automated Service quality Scale was respectively found ATMS 0.727, IBS 0.739 , TBS 0.777 with original items of Al- Hawari [49-54]. This result showed 
that the value of reliability of this scale is satisfactory in Pakistan and there is no need to remove any item from original scale. Effect on alpha value of this scale is shown in the following Tables 1-4.

\section{Results and Discussion}

This part of paper explains and discussing the results of the study as findings suggests the relationship between study variables.

\section{Demographic information}

The demographic information of respondent's shows 170 were male and rest of belongs to female. The leading age group (72\%) was between 18 to 28 years, the second largest age group was $29-38$ with $26.40 \%$ from the respondents, where $11 \%$ was undergraduates, $64 \%$ has Master level education and $11.20 \%$ was $\mathrm{M}$. Phil. The leading income group in this study was PKR 31000 to 50000 with $45.20 \%$, by less than income PKR 30000 were $26.20 \%$, between PKR. 51000 to 70000 were $13.60 \%$, from PKR. 71000 to 90000 were $7.2 \%$ and more than PKR. 90000 were $7.2 \%$. The respondents visit once every fortnight were $56.80 \%, 12.40 \%$ twice a week, and $6.80 \%$ once a week and once in a month were also

\begin{tabular}{|c|c|c|c|}
\hline Sr.No & Demographic Items & $\begin{array}{l}\text { Number of } \\
\text { respondents }\end{array}$ & Percentage \\
\hline \multirow{6}{*}{1} & Age & & \\
\hline & $18-28$ & 180 & $72 \%$ \\
\hline & $29-38$ & & \\
\hline & $39-48$ & 66 & $26.40 \%$ \\
\hline & 49- 58 & 4 & $1.60 \%$ \\
\hline & Over 59 & & \\
\hline \multirow{3}{*}{2} & Gender & & \\
\hline & Female & 80 & $32 \%$ \\
\hline & Male & 170 & $68 \%$ \\
\hline \multirow{4}{*}{3} & Education & & \\
\hline & Bachelors & 29 & $11 \%$ \\
\hline & Masters & 161 & $64.00 \%$ \\
\hline & M.Phil / MS & 28 & $11.20 \%$ \\
\hline \multirow{6}{*}{4} & Income & & \\
\hline & Less than PKR. 30000 & 67 & $26.80 \%$ \\
\hline & PKR. $31000-50000$ & 113 & $45.20 \%$ \\
\hline & PKR.51000 -70000 & 34 & $13.60 \%$ \\
\hline & PKR. 71000 - 90000 & 18 & $7.20 \%$ \\
\hline & More than PKR.91000 & 18 & $7.20 \%$ \\
\hline
\end{tabular}

Table 1: Demographic characteristics of the respondents.

\begin{tabular}{|c|c|}
\hline No. of Items & Cronbach's Alpha \\
\hline IBS1 & 0.702 \\
\hline IBS2 & 0.701 \\
\hline IBS3 & 0.763 \\
\hline IBS4 & 0.73 \\
\hline IBS5 & 0.701 \\
\hline IBS6 & 0.74 \\
\hline IBS7 & 0.725 \\
\hline
\end{tabular}

Table 2: Internet Banking Services (TBS).

\begin{tabular}{|c|c|}
\hline No. of Items & Cronbach's Alpha value \\
\hline TBS1 & 0.721 \\
\hline TBS2 & 0.76 \\
\hline TBS3 & 0.772 \\
\hline TBS4 & 0.73 \\
\hline TBS5 & 0.717 \\
\hline TBS6 & 0.759 \\
\hline
\end{tabular}

Table 3: Telephone banking services (TBS).

\begin{tabular}{|c|c|}
\hline No. of Items & Cronbach's Alpha \\
\hline ATMS 1 & 0.734 \\
\hline ATMS 2 & 0.707 \\
\hline ATMS 3 & 0.718 \\
\hline ATMS 4 & 0.717 \\
\hline ATMS 5 & 0.729 \\
\hline ATMS 6 & 0.709 \\
\hline ATMS 7 & 0.703 \\
\hline
\end{tabular}

Table 4: Automated Teller Machine Services (ATM).

\begin{tabular}{|c|c|}
\hline No. of Items & Cronbach's Alpha \\
\hline OS 1 & 0.874 \\
\hline OS 2 & 0.858 \\
\hline OS 3 & 0.916 \\
\hline OS 4 & 0.858 \\
\hline OS 5 & 0.916 \\
\hline OS 6 & 0.858 \\
\hline
\end{tabular}

Table 5: Overall Satisfactions (OS)

\begin{tabular}{|c|c|c|c|c|c|}
\hline & N & Min & Max & Mean & $\begin{array}{c}\text { Std. } \\
\text { Deviation }\end{array}$ \\
\hline Age & 250 & 22 & 45 & 26.752 & 4.069 \\
\hline Gender & 250 & 1 & 2 & 1.6 & 0.49088 \\
\hline Education & 250 & 1 & 3 & 2.192 & 0.50214 \\
\hline Income & 250 & 1 & 5 & 2.224 & 1.12913 \\
\hline Bank & 250 & 1 & 5 & 3.312 & 1.32275 \\
\hline Visit & 250 & 1 & 6 & 3.8 & 1.2321 \\
\hline ATMS & 250 & 2.4 & 5 & 3.8848 & 0.49431 \\
\hline MBS & 250 & 0 & 4.83 & 3.492 & 0.77164 \\
\hline IBS & 250 & 1 & 4.57 & 3.4823 & 0.78647 \\
\hline OS & 250 & 1.67 & 5 & 3.928 & 0.71209 \\
\hline
\end{tabular}

Table 6: Descriptive analysis of study variables.

$6.80 \%$. these finding shows that the representative sample of the whole population in this study captured from different point of view people from a huge broad range of age group who had an average level of income and had well educated rational people who visit their bank many time in a month and expect a quality services from their banks [55-58].

\section{Reliability of customer satisfaction}

The Cronbach alpha coefficient value for customer satisfaction scale was found 0.818 with six items and this is satisfactory. So no item was deleted from this scale [59,60]. Effect on alpha value of this scale is shown in the following Table 5.

Descriptive statistics of demographics variables and four study variables are shown in Table 6 . For $n=250$, minimum, maximum and mean values of each variable are presented along with standard deviations.

\section{Correlation analysis}

Correlation analysis commonly used to measure the level of relationship between all types of variables. Correlation show that how strongly the pairs of independent and dependent variables has been related to each other [61-63]. The value of this statistical tool ranges from -1 to +1 . If relation is close to zero, that means there is no relation among the variables. If result shown positive relationship, it means that when the value of one variable increases then the value of other variable will also increases, and in term of negative relationship, if the value of one variable decreases the others will also decreases (it may be called as inverse relationship) $[64,65]$. 
Pearson Correlation matrix has been used to measure the inter relationship between the studied variables, table, shows the results of correlation analysis. All the results are briefly explained below. Correlation between ATM services and C is $0.412^{* *}$ that is significant at 0.01 levels. This value is showing that these two variables have significant and positive relationship with each other. The relationship between ATM services and customer satisfaction was found significant and positive [66-68]. The correlation of $0.583^{* *}$ is significant at 0.01 for these two variables. Correlation between mobile banking services and internet banking services is $0.443^{\star *}$ that is significant at 0.01 levels. This value shows that these two variables MBS and IBS have significant and positive relationship with each other-as presented in Table 7 . Correlation between mobile banking services and customer satisfaction was found $0.375^{\star *}$ and it is significant at levels of 0.01 . This value shows that these two variables MBS and OSF have significant and positive relationship with each other-as presented in Table 7. The relationship between internet banking services and customer satisfaction was found significant and positive. The correlation of $0.299^{* *}$ is significant at 0.01 for these two variables.

\section{Regression results}

The impact of automated services ATMs quality services, Mobile banking quality services and Internet banking quality services measured. Table 8 shows the results that all automated services are significantly affecting the customer satisfaction. Results shows that ATM services has a positive significant strong impact on customer satisfaction $(\beta=0.536$, $p<0.001)$, Mobile banking services also effect the satisfaction $(\beta=0.405$, $\mathrm{p}<0.001)$ comparatively Internet banking services are also has a positive significant relationship with customer satisfaction $(\beta=0.316, \mathrm{p}<0.001)$. the results show that ATMS services has a strong effect on customer satisfaction as compare to Mobile baking and internet banking services.

The results of Regression for ATM Services, Mobile banking services and internet banking services to Customer Satisfaction are above. All the variables have a significant strong impact on customer satisfaction. So for the purpose of studying the impact of automated service on the customer satisfaction, we test the services separately. ATM services have the strongest impact on overall satisfaction, while the mobile services and internet services have comparatively low impact on the customer satisfaction [69].

\section{Conclusion}

The results have shown three main findings. First, it was found that

\begin{tabular}{|c|c|c|c|c|}
\hline Variables & $\mathbf{1}$ & $\mathbf{2}$ & $\mathbf{3}$ & $\mathbf{4}$ \\
\hline ATM Services & 1 & 1 & & \\
\hline $\begin{array}{c}\text { Mobile banking } \\
\text { services }\end{array}$ & $0.388^{* *}$ & $0.443^{* *}$ & 1 & 1 \\
\hline $\begin{array}{c}\text { Internet banking } \\
\text { services }\end{array}$ & $0.412^{* *}$ & $0.375^{* *}$ & $0.290^{* *}$ & 1 \\
\hline $\begin{array}{c}\text { Customer } \\
\text { satisfaction }\end{array}$ & $0.583^{* *}$ & & \\
\hline
\end{tabular}

${ }^{*}$. Correlation is significant at the 0.01 level (2-tailed).

Table 7: Correlation analysis.

\begin{tabular}{|c|c|c|c|}
\hline $\begin{array}{c}\text { Customer Satisfaction } \\
\text { Variables }\end{array}$ & Constant & $\boldsymbol{\beta}$ & $\mathbf{R}^{\mathbf{2}}$ \\
\hline ATMS & 0.998 & $0.536^{* *}$ & 0.24 \\
\hline MBS & 0.989 & $0.405^{\star *}$ & 0.327 \\
\hline IBS & 0.997 & $0.316^{* *}$ & 0.379 \\
\hline${ }^{* * P<0.001}$ & & & \\
\hline
\end{tabular}

Table 8: Regression results. automated service and traditional service quality (human interaction) both have direct significant effect on customer satisfaction. Second, the results find that an insignificant relationship between ATM services on customer satisfaction when moderated by Traditional Banking services, and directly this services play an important role to satisfy the customer. Thirdly, results found a strong positive significant association in Mobile banking services and internet banking services moderated by teller banking services.

The previous literature revealed that the importance of traditional services quality still an effective way of creating a strong marketing relationship. Furthermore, this study established that services quality in the traditional and automated banking context has a significant influence on customer satisfaction. So, to establish a long term relationship with customers by using only automated services is not an easy way because the quality matters with automated services cannot be put apart, and traditional service quality and automated services are not the alternative to each other but they are complementary to each other. An efficient way is that banks should first priority to improve the quality of direct personal interactions to counter for the associated risk and uncertainty then they should focus on the quality issue of automated services. So banks should never ignore the importance of direct face to face interactions, as the quality issue associated to automated services can drop the banks competitive edges and as will as affect the profitability. For this reason, the associated problems of quality issues with automated services should not be the only focus for the bank manager, it is very much essential to recognize the human factor in respect of quality services.

The managerial implication of this study indicates that banks should pay continuous attention in the training and development of their employees who have direct interaction with the valuable customers to improve the overall customer satisfaction. However, satisfaction with technological communication is an indispensable and a significant predictor of overall satisfaction. Bitner et al. [49] assert that offering both types of service encounters, technologically or interpersonally based, is critical to ensure the overall satisfaction of customers. Further, customers are contacting these service organizations through multiple channels so a plan for integrating service across channels is necessary.

\section{References}

1. Blose JE, Tankersley WB, Flynn LR (2005) Managing service quality using data envelopment analysis. Quality Management Journal On-line 12: 1-18.

2. Avkiran NK (1994) Developing an instrument to measure customer service quality in branch banking. International journal of bank marketing 12: 10-18.

3. Yavas U, Benkenstein M, Stuhldreier U (2004) Relationships between service quality and behavioral outcomes: a study of private bank customers in Germany. International Journal of Bank Marketing 22: 144-157.

4. Chumpitaz R, Paparoidamis NG (2004) Service quality and marketing performance in business-to-business markets: exploring the mediating role of client satisfaction. Managing Service Quality 14: 235-248.

5. Lang B, Colgate M (2003) Relationship quality, on-line banking and the information technology gap. International Journal of Bank Marketing 21: 29-37.

6. Joseph M, Stone G (2003) An empirical evaluation of US bank customer perceptions of the impact of technology on service delivery in the banking sector. International Journal of Retail \& Distribution Management 31: 190-202.

7. ZeithamI VA (2000) Service quality, profitability, and the economic worth of customers: what we know and what we need to learn. Journal of the Academy of Marketing Science 28: 67-85.

8. Al-Hawari M, Ward T (2006) The effect of automated service quality on Australian banks' financial performance and the mediating role of customer satisfaction. Marketing Intelligence \& Planning 24: 127-147. 
Citation: Shabbir MS, Rehma AK, Shabbir T (2016) Combine Effect of Automated Services and Traditional Services Quality on Customer Satisfaction: Evidence from Banking Sector of Pakistan. Int J Econ Manag Sci 5: 332. doi:10.4172/2162-6359.1000332

Page 7 of 8

9. Brandman J, Keeler D (2000) Rewiring Europe's banks. Global Finance 14: 49-51.

10. Meuter ML, Ostrom AL, Bitner MJ, Roundtree R (2003) The influence of technology anxiety on consumer use and experiences with self-service technologies. Journal of Business Research 56: 899-906.

11. Anderson RE, Srinivasan SS (2003) E $\square$ satisfaction and e $\square$ loyalty: A contingency framework. Psychology \& Marketing 20: 123-138.

12. Ibbotson P, Moran L (2003) E-banking and the SME/bank relationship in Northern Ireland. International Journal of Bank Marketing 21: 94-103.

13. Curry A, Penman S (2004) The relative importance of technology in enhancing customer relationships in banking-a Scottish perspective. Managing Service Quality 14: 331-341.

14. Van Riel AC, Liljander V, Jurriens $P$ (2001) Exploring consumer evaluations of e-services: a portal site. International Journal of Service Industry Management 12: 359-377.

15. Shabbir MS (2014) The impact of human resource practices on employee perceived performance in pharmaceutical sector of Pakistan. African Journal of Business Management 8: 626-632.

16. Shahzad M, Rehman A (2015) Barriers to Service Quality in the Banks of Pakistan: A Comparative Study of Islamic and Conventional Banks. Business and Economics Journal 6: 178

17. Jamal A, Naser K (2003) Factors influencing customer satisfaction in the retail banking sector in Pakistan. International journal of commerce and management 13: 29-53.

18. Kohli AK, Jaworski BJ (1990) Market orientation: the construct, research propositions, and managerial implications. The Journal of Marketing 54: 1-18.

19. Abdullah A, Dayang NM, Rozario $F(2009)$ Influence of service and product quality towards customer satisfaction: A case study at the staff cafeteria in the hotel industry. World Academy of Science, Engineering and Technology 53: 185-190.

20. Fornell C (1992) A national customer satisfaction barometer: The Swedish experience. The Journal of Marketing 56: 6-21.

21. Gardener E, Howcroft B, Williams (1999) The new retail banking revolution The Service Industries Journal 19: 83-100.

22. Idowu PA, Alu A, Adagunodo ER (2002) The effect of information technology on the growth of the banking industry in Nigeria. The Electronic Journal of Information Systems in Developing Countries 10

23. Lundvall BA (1988) Innovation as an interactive process: from user-producer interaction to the national system of innovation. Technical change and economic theory 369 .

24. Mouawad M, Kleiner BH (1996) New developments in customer service training. Managing Service Quality 6: 49-56.

25. Levesque T, McDougall GH (1996) Determinants of customer satisfaction in retail banking. International Journal of Bank Marketing 14: 12-20.

26. Santos J (2003) E-service quality: a model of virtual service quality dimensions. Managing service quality 13: 233-246.

27. Cronin Jr JJ, Taylor SA (1992) Measuring service quality: a reexamination and extension. The journal of marketing 56: 55-68.

28. Athanassopoulos A, Gounaris S, Stathakopoulos V (2001) Behavioural responses to customer satisfaction: an empirical study. European Journal of Marketing 35: 687-707.

29. Brodie RJ, Coviello NE, Brookes RW, Little V (1997) Towards a paradigm shift in marketing? An examination of current marketing practices. Journal of Marketing Management 13: 383-406.

30. Acharya RN, Kagan A, Lingam SR (2008) Online banking applications and community bank performance. International Journal of Bank Marketing 26: 418-439.

31. Zineldin M (2000) Beyond relationship marketing: technologicalship marketing. Marketing Intelligence \& Planning 18: 9-23.

32. Wong DH, Rexha N, Phau I (2008) Re-examining traditional service quality in an e-banking era. International Journal of Bank Marketing 26: 526-545.
33. Filotto U, Tanzi PM, Saita F (1997) Customer needs and front-office technology adoption. International Journal of Bank Marketing 15: 13-21.

34. Hway-Boon O, Yu CM (2003) Success factors in e-channels: the Malaysian banking scenario. International Journal of Bank Marketing 21: 369-377.

35. Mols NP (1998) The behavioral consequences of PC banking. International Journal of Bank Marketing 16: 195-201.

36. Parasuraman A, Berry LL, Zeihaml VA (1988) SERVQUAL: A Multiple Item Scale For Measuring Consumer Perceptions of Service Quality. Journal of Retailing 64: 12-40.

37. Parasuraman A, Zeithaml VA, Berry LL (1985) A conceptual model of service quality and its implications for future research. The Journal of Marketing 49 : $41-50$.

38. Parasuraman A, Zeithaml VA, Malhotra A (2005) ES-QUAL a multiple-item scale for assessing electronic service quality. Journal of service research 7 : 213-233.

39. Joseph M, McClure C, Joseph B (1999) Service quality in the banking sector: the impact of technology on service delivery. International Journal of Bank Marketing 17: 182-193.

40. Reinders MJ, Dabholkar PA, Frambach RT (2008) Consequences of forcing consumers to use technology-based self-service. Journal of Service Research 11: 107-123.

41. Ramsay J, Smith M (1999) Managing customer channel usage in the Australian banking sector. Managerial Auditing Journal 14: 329-338.

42. Phillips LA, Calantone R, Lee MT (1994) International technology adoption: Behavior structure, demand certainty and culture. Journal of Business \& Industrial Marketing 9: 16-28

43. Santouridis I, Trivellas P, Reklitis $P$ (2009) Internet service quality and customer satisfaction: Examining internet banking in Greece. Total Quality Management 20: 223-239.

44. Durkin M, McCartan-Quinn D, O'Donnell A, Howcroft B (2003) Retail bank customer preferences: personal and remote interactions. International Journal of Retail \& Distribution Management 31: 177-189.

45. Tyler K, Stanley E (2001) Corporate banking: the strategic impact of boundary spanner effectiveness. International Journal of Bank Marketing 19: 246-261.

46. Herington C, Weaven S (2007) Can banks improve customer relationships with high quality online services?. Managing Service Quality 17: 404-427.

47. Neuman WL (2003) Social research methods: qualitative and quantitative approach. 5th edn, Pearson education, Inc, Sydney.

48. Cronbach LJ (1951) Coefficient alpha and the internal structure of tests. Psychometrika, 16: 297-334.

49. Bitner MJ, Hubbert AR (1994) Encounter satisfaction versus overall satisfaction versus quality. Service quality: New directions in theory and practice pp: 72-94

50. Amiri ASF, Faghani F (2012) Mobile Banking Service Quality and Customer Satisfaction (Application of SERVQUAL Model). International Journal of Management and Business Research 2: 351-361.

51. Arasli H, Mehtap-Smadi S, Katircioglu ST (2005) Customer service quality in the Greek Cypriot banking industry. Managing Service Quality: An International Journal 15: 41-56.

52. Ariff MSM, Yun LO, Zakuan N, Ismail K (2013) The Impacts of Service Quality and Customer Satisfaction on Customer Loyalty in Internet Banking. ProcediaSocial and Behavioral Sciences 81: 469-473.

53. Ataullah A, Cockerill T, Le H (2004) Financial liberalization and bank efficiency: a comparative analysis of India and Pakistan. Applied Economics 36: 1915 1924.

54. Baloch QB, Zahid M (2011) Impact of Information Technology on E-Banking: Evidence from Pakistan's Banking Industry. Abasyn Journal of Social Sciences 4: 241-263.

55. Babakus E, Boller GW (1992) An empirical assessment of the SERVQUAL scale. Journal of Business research 24: 253-268.

56. Bearden WO, Teel JE (1983) Selected determinants of consumer satisfaction and complaint reports. Journal of marketing Research 20: 21-28. 
Citation: Shabbir MS, Rehma AK, Shabbir T (2016) Combine Effect of Automated Services and Traditional Services Quality on Customer Satisfaction: Evidence from Banking Sector of Pakistan. Int J Econ Manag Sci 5: 332. doi:10.4172/2162-6359.1000332

Page 8 of 8

57. Beck T, Levine R, Loayza N (2000) Finance and the Sources of Growth. Journal of financial economics 58: $261-300$

58. Bontis N, Booker LD, Serenko A (2007) The mediating effect of organizational reputation on customer loyalty and service recommendation in the banking industry. Management Decision 45: 1426-1445.

59. Buttle F (1996) SERVQUAL: review, critique, research agenda. European Journal of marketing, 30: 8-32.

60. Churchill Jr GA, Surprenant C (1982) An investigation into the determinants of customer satisfaction. Journal of Marketing research 19: 491-504.

61. Cobas MG, Mote LR, Wilcox JA (2003) A history of the future of banking: Predictions and outcomes. The future of banking pp: 49-76.

62. Davies F, Moutinho L, Curry B (1996) ATM user attitudes: a neural network analysis. Marketing Intelligence \& Planning 14: 26-32.

63. Dosi G, Freeman C, Nelson R, Silverberg G, Soete LL (1988) Technical change and economic theory, Pinter Publishers, USA.
64. Jones MA, Suh J (2000) Transaction-specific satisfaction and overall satisfaction: an empirical analysis. Journal of Services Marketing 14: 147-159.

65. Lewis BR, Orledge J, Mitchell VW (1994) Service Quality:: Students' Assessment of Banks and Building Societies. International journal of bank marketing 12: 3-12.

66. Lewis BR (1993) Service quality: definitions, determinants and measurement. Training for Quality 1.

67. Lin C, Chow WS, Madu CN, Kuei CH, Yu PP, et al. (2005) A structural equation model of supply chain quality management and organizational performance. International Journal of Production Economics 96: 355-365.

68. Lin RJ, Chen RH, Chiu KKS (2010) Customer relationship management and innovation capability: an empirical study. Industrial Management \& Data Systems 110: 111-133.

69. Semeijn J, Van Riel AC, Van Birgelen MJ, Streukens S (2005) E-services and offline fulfilment: how e-loyalty is created. Managing Service Quality 15: 182194. 